\title{
Tomato Cultivation Systems Affect Subsequent Quality of Fresh-cut Fruit Slices
}

\author{
Ji Heun Hong \\ Horticultural Crops Quality Laboratory, Building 002, Beltsville Agricultural Research Center, Agricultural \\ Research Service, U.S. Department of Agriculture, 10300 Baltimore Avenue, Beltsville, MD 20705-2350
}

\author{
Douglas J. Mills, C. Benjamin Coffman, and James D. Anderson \\ Weed Science Laboratory, Building 001, Beltsville Agricultural Research Center, Agricultural Research \\ Service, U.S. Department of Agriculture, 10300 Baltimore Avenue, Beltsville, MD 20705-2350
}

Mary J. Camp

Biometrical Consulting Service, Building 005, Beltsville Agricultural Research Center, Agricultural Research Service, U.S. Department of Agriculture, 10300 Baltimore Avenue, Beltsville, MD 20705-2350

\begin{abstract}
Kenneth C. Gross ${ }^{1}$
Horticultural Crops Quality Laboratory, Building 002, Beltsville Agricultural Research Center, Agricultural Research Service, U.S. Department of Agriculture, 10300 Baltimore Avenue, Beltsville, MD 20705-2350
\end{abstract}

\begin{abstract}
AdDitional INDEX WORDS. Lycopersicon esculentum, chilling injury, minimally processed, sustainable agricultural systems, Vicia villosa

Abstract. Experiments were conducted to compare changes in quality of slices of red tomato (Lycopersicon esculentum Mill. 'Sunbeam') fruit from plants grown using black polyethylene or hairy vetch mulches under various foliar disease management systems including: no fungicide applications (NF), a disease forecasting model (ToM-CAST), and weekly fungicide applications (WF), during storage at $5{ }^{\circ} \mathrm{C}$ under a modified atmosphere. Slices were analyzed for firmness, soluble solids content (SSC), titratable acidity (TA), pH, electrolyte leakage, fungi, yeasts, and chilling injury. With both NF and ToM-CAST fungicide treatments, slices from tomatoes grown with hairy vetch (Vicia villosa Roth) mulch were firmer than those from tomatoes grown with black polyethylene mulch after 12 days storage. Ethylene production of slices from fruit grown using hairy vetch mulch under ToM-CAST was $\approx 1.5$ - and 5-fold higher than that of slices from WF and NF fungicide treatments after 12 days, respectively. The percentage of water-soaked areas (chilling injury) for slices from tomatoes grown using black polyethylene mulch under NF was over 7-fold that of slices from tomatoes grown using hairy vetch under ToM-CAST. When stored at $20^{\circ} \mathrm{C}$, slices from light-red tomatoes grown with black polyethylene or hairy vetch mulches both showed a rapid increase in electrolyte leakage beginning 6 hours after slicing. However, slices from tomatoes grown using the hairy vetch mulch tended to have lower electrolyte leakage than those grown with black polyethylene mulch. These results suggest that tomatoes from plants grown using hairy vetch mulch may be more suitable for fresh-cut slices than those grown using black polyethylene mulch. Also, use of the disease forecasting model ToM-CAST, which can result in lower fungicide application than is currently used commercially, resulted in high quality fruit for fresh-cut processing.
\end{abstract}

Tomatoes (Lycopersicon esculentum) are grown conventionally either on plastic mulches or in bare soil. In particular, black polyethylene is used most commonly as a mulch commercially in the production of fresh-market field tomatoes (Hochmuth et al., 1986). Synthetic mulches, including black polyethylene, are used commonly for early production (West and Pierce, 1988), high yield (Abdul-Baki et al., 1992; Bhella, 1988), good fruit quality (Perry and Sanders, 1986) and for weed control (Teasdale and Colacicco, 1985). However, installation and removal of polyethylene mulches require specialized equipment and involve relatively high costs.

A sustainable agricultural production system has been developed for summer vegetables, including tomatoes, in which hairy

Received for publication 6 Jan. 2000. Accepted for publication 10 July 2000. Use of a company or product name by the USDA does not imply approval or recommendation of the product to the exclusion of others that may also be suitable. We would like to express our appreciation to the Korea Science and Engineering Foundation for financial assistance to partially support J.H.H. The cost of publishing this paper was defrayed in part by the payment of page charges. Under postal regulations, this paper therefore must be hereby marked advertisement solely to indicate this fact.

${ }^{1}$ Corresponding author. vetch (Vicia villosa) was used as a cover crop alone (Abdul-Baki and Teasdale, 1993) or in combination with other legumes and grasses (Stivers and Shennan, 1991). Many studies have been published dealing with various effects of winter legumes as cover crop mulches; they reduce soil erosion (Shelton and Bradley, 1987), improve soil organic content (Stivers and Shennan, 1991), increase soil water-holding capacity (Hoyt and Hargrove, 1986), reduce weed competition and the need for herbicides (Sloderbeck and Edwards, 1979), reduce the need for fungicides (Sloderbeck and Edwards, 1979), and provide significant amounts of $\mathrm{N}$ to subsequently grown nonleguminous crops (McVay et al., 1989).

Abdul-Baki et al. (1996) reported that yields were higher, fruit were heavier, and leaf necrosis was lower in plants grown using hairy vetch than with black polyethylene. They also reported that dry weight was higher and $\mathrm{pH}$ lower in tomatoes grown using black polyethylene mulch compared with hairy vetch, but there was no difference in soluble solids content between black polyethylene and hairy vetch mulch. In general, plastic mulches increase the range of soil temperature fluctuation compared with bare soil (Ham et al., 1993). However, organic mulches decrease the maximum and increase the minimum soil temperature (Teasdale and Mohler, 1993). 
Weekly fungicide applications are used commonly to reduce disease severity in commercial production of fresh market tomatoes. However, frequent fungicide use results in ground water contamination and increased resistance of pathogens to pesticides (Haynes et al., 1986). Thus, there exists a need to investigate alternative methods of pest control, such as integrated pest management (IPM) and use of disease forecasting models like TOM-CAST, that minimize fungicide and other pesticide use within conventional and sustainable production systems. Trumble et al. (1994) reported that use of IPM in fresh market tomatoes has significant benefits, such as a reduction in potential development of fungicide resistance, reduced soil compaction, less environmental contamination, and reduction in human health concerns.

While the effects of mulches and IPM in sustainable systems on plant growth, yield, and environmental impact have been studied, we were interested in the effects of sustainable systems on postharvest tomato quality, particularly the quality of freshcut slices. Thus, the objective of this study was to compare quality during storage of fresh-cut slices from red-ripe tomatoes grown with different mulches and fungicide applications.

\section{Materials and Methods}

FiELD EXPERIMENTS. Experiments were conducted at the South Farm of the Beltsville Agricultural Research Center, Beltsville,
Md., in 1997 and 1999. Site preparation began in Sept. 1996 and 1998 by sowing hairy vetch seeds, at a rate of $44.4 \mathrm{~kg} \cdot \mathrm{ha}^{-1}$ on raised beds. The beds were $1.5 \mathrm{~m}$ from center to center and $15 \mathrm{~cm}$ in height. In early May, black polyethylene was laid on the raised beds and trickle irrigation lines positioned beneath the black polyethylene. Preemergent weed control within black polyethylene plots was accomplished by incorporating napropamide [ $N, N$-diethyl-2-(1-naphthylenoxy)-propanamide] at a rate of 1.56 $\mathrm{kg} \cdot \mathrm{ha}^{-1}$. On 28 May 1997 and 20 May 1999, the hairy vetch plots were mown with a high speed-flail mower positioned $\approx 5 \mathrm{~cm}$ above the soil surface to kill the cover crop and create a layer of organic mulch on the bed surface. Postemergence weed management in both mulch systems during the growing season was achieved by spot applications of glyphosate ( $N$-phosphonomethyl glycine).

'Sunbeam', a popular fresh-market tomato cultivar, was used in this study. Each seedling received an insecticide treatment of $95.2 \mathrm{mg}$ of imidacloprid, 1-[(6-chloro-3-pyridinyl) methyl]- $N$ nitro-2-imidazolidinimine, before transplant. This treatment was intended to minimize seedling damage by Colorado potato beetle (Leptinotarsa decemlineata) in the field. Seedlings were transplanted mechanically at a distance of $0.38 \mathrm{~m}$ apart on 29 May 1997 and 21 May 1999. Shortly after seedling transplant, a trickle irrigation system was installed on the hairy vetch beds. Irrigation lines were placed on the bed surface $\approx 15 \mathrm{~cm}$ from the seedlings. The rate of irrigation was $2.5 \mathrm{~cm}$ per week. About 1 month after

Table 1. Changes in fruit quality of fresh-cut, red-ripe slices from tomatoes grown using black polyethylene or hairy vetch mulch and various foliar disease management systems. Fruit were stored at $5^{\circ} \mathrm{C}$ under modified atmosphere.

\begin{tabular}{|c|c|c|c|c|c|c|c|c|c|}
\hline $\begin{array}{l}\text { Days in } \\
\text { storage }\end{array}$ & Treatment $^{2}$ & $\begin{array}{l}\text { Firmness } \\
\text { (N) }\end{array}$ & $\begin{array}{c}\mathrm{SSC} \\
(\%)\end{array}$ & TA & $\begin{array}{l}\mathrm{SSC} \text { to } \\
\mathrm{TA} \text { ratio }\end{array}$ & $\mathrm{pH}$ & $\begin{array}{l}\mathrm{EL}^{\mathrm{y}} \\
(\%)\end{array}$ & $\begin{array}{l}\text { Fungi } \\
(\mathrm{cfu} / \mathrm{g})\end{array}$ & $\begin{array}{l}\text { Yeast } \\
(\mathrm{cfu} / \mathrm{g})\end{array}$ \\
\hline \multirow[t]{6}{*}{$\overline{0}$} & B-NF & $1.39 \mathrm{~b}^{\mathrm{x}}$ & $4.37 \mathrm{~d}$ & $0.50 \mathrm{c}$ & $7.78 \mathrm{~b}$ & $4.50 \mathrm{a}$ & $35.0 \mathrm{a}$ & $--^{w}$ & --- \\
\hline & B-TC & $1.56 \mathrm{ab}$ & $4.69 \mathrm{~cd}$ & $0.39 \mathrm{~d}$ & $11.32 \mathrm{a}$ & $4.45 \mathrm{~b}$ & $36.0 \mathrm{a}$ & --- & --- \\
\hline & B-WF & $1.54 \mathrm{ab}$ & $4.84 \mathrm{bc}$ & $0.38 \mathrm{de}$ & $11.88 \mathrm{a}$ & $4.45 \mathrm{~b}$ & $31.0 \mathrm{a}$ & --- & --- \\
\hline & $\mathrm{H}-\mathrm{NF}$ & $1.57 \mathrm{ab}$ & $4.79 \mathrm{c}$ & $0.36 \mathrm{e}$ & $11.68 \mathrm{a}$ & $4.39 \mathrm{c}$ & $33.3 \mathrm{a}$ & --- & --- \\
\hline & H-TC & $1.69 \mathrm{a}$ & $5.05 \mathrm{a}$ & $0.62 \mathrm{~b}$ & $7.76 \mathrm{~b}$ & $4.37 \mathrm{c}$ & $35.3 \mathrm{a}$ & --- & --- \\
\hline & H-WF & $1.55 \mathrm{ab}$ & $4.99 \mathrm{ab}$ & $0.72 \mathrm{a}$ & $6.20 \mathrm{c}$ & $4.38 \mathrm{c}$ & $28.7 \mathrm{a}$ & --- & --- \\
\hline \multirow[t]{6}{*}{4} & $\mathrm{~B}-\mathrm{NF}$ & $1.33 \mathrm{~b}$ & $4.51 \mathrm{c}$ & $0.52 \mathrm{~b}$ & $7.45 \mathrm{c}$ & $4.54 \mathrm{a}$ & $38.0 \mathrm{a}$ & --- & --- \\
\hline & B-TC & $1.53 \mathrm{ab}$ & $5.12 \mathrm{ab}$ & $0.38 \mathrm{c}$ & $12.95 \mathrm{a}$ & $4.51 \mathrm{ab}$ & $34.3 \mathrm{a}$ & --- & --- \\
\hline & B-WF & $1.66 \mathrm{a}$ & $4.96 \mathrm{~b}$ & $0.34 \mathrm{c}$ & $12.20 \mathrm{a}$ & $4.49 \mathrm{~b}$ & $33.7 \mathrm{a}$ & --- & --- \\
\hline & $\mathrm{H}-\mathrm{NF}$ & $1.46 \mathrm{ab}$ & $5.01 \mathrm{~b}$ & $0.51 \mathrm{~b}$ & $9.07 \mathrm{~b}$ & $4.45 \mathrm{c}$ & $32.3 \mathrm{a}$ & --- & --- \\
\hline & H-TC & $1.54 \mathrm{ab}$ & $5.25 \mathrm{a}$ & $0.56 \mathrm{ab}$ & $8.50 \mathrm{~b}$ & $4.40 \mathrm{~d}$ & $31.3 \mathrm{a}$ & --- & --- \\
\hline & H-WF & $1.69 \mathrm{a}$ & $4.93 \mathrm{~b}$ & $0.65 \mathrm{a}$ & $6.98 \mathrm{c}$ & $4.41 \mathrm{~d}$ & $30.3 \mathrm{a}$ & --- & --- \\
\hline \multirow[t]{6}{*}{8} & $\mathrm{~B}-\mathrm{NF}$ & $1.42 \mathrm{bc}$ & $4.33 \mathrm{e}$ & $0.39 \mathrm{~cd}$ & $9.45 \mathrm{~b}$ & $4.55 \mathrm{a}$ & $35.3 \mathrm{a}$ & --- & --- \\
\hline & B-TC & $1.37 \mathrm{c}$ & $4.79 \mathrm{~cd}$ & $0.35 \mathrm{~d}$ & $12.34 \mathrm{a}$ & $4.52 \mathrm{~b}$ & $45.7 \mathrm{a}$ & --- & --- \\
\hline & B-WF & $1.76 \mathrm{a}$ & $4.97 \mathrm{bc}$ & $0.41 \mathrm{c}$ & $11.16 \mathrm{a}$ & $4.52 \mathrm{~b}$ & $41.7 \mathrm{a}$ & --- & --- \\
\hline & $\mathrm{H}-\mathrm{NF}$ & $1.42 \mathrm{bc}$ & $4.60 \mathrm{~d}$ & $0.51 \mathrm{~b}$ & $7.66 \mathrm{c}$ & $4.50 \mathrm{~b}$ & $39.3 \mathrm{a}$ & --- & --- \\
\hline & H-TC & $1.59 \mathrm{ab}$ & $5.19 \mathrm{a}$ & $0.47 \mathrm{~b}$ & $10.16 \mathrm{ab}$ & $4.36 \mathrm{c}$ & $38.0 \mathrm{a}$ & --- & --- \\
\hline & H-WF & $1.55 \mathrm{abc}$ & $5.13 \mathrm{ab}$ & $0.62 \mathrm{a}$ & $7.67 \mathrm{c}$ & $4.39 c$ & $39.3 \mathrm{a}$ & --- & --- \\
\hline \multirow[t]{6}{*}{12} & $\mathrm{~B}-\mathrm{NF}$ & $0.82 \mathrm{c}$ & $3.72 \mathrm{c}$ & $0.30 \mathrm{f}$ & $9.45 \mathrm{~b}$ & $4.63 \mathrm{a}$ & $63.0 \mathrm{a}$ & $21 \mathrm{a}$ & $7.8 \times 10^{3} a$ \\
\hline & B-TC & $1.30 \mathrm{~b}$ & $4.43 \mathrm{~b}$ & $0.35 \mathrm{e}$ & $10.84 \mathrm{a}$ & $4.51 \mathrm{~b}$ & $47.7 \mathrm{~b}$ & $0 \mathrm{~b}$ & $2.9 \times 10^{2} \mathrm{~b}$ \\
\hline & B-WF & $1.38 \mathrm{ab}$ & $4.54 \mathrm{~b}$ & $0.39 \mathrm{~d}$ & $10.08 \mathrm{ab}$ & $4.46 \mathrm{c}$ & $45.0 \mathrm{~b}$ & $0 \mathrm{~b}$ & $0 \mathrm{c}$ \\
\hline & $\mathrm{H}-\mathrm{NF}$ & $1.45 \mathrm{ab}$ & $4.60 \mathrm{ab}$ & $0.47 \mathrm{c}$ & $8.80 \mathrm{c}$ & $4.49 \mathrm{bc}$ & $43.0 \mathrm{~b}$ & $0 \mathrm{~b}$ & $6.9 \times 10^{2} \mathrm{~b}$ \\
\hline & H-TC & $1.59 \mathrm{a}$ & $4.93 \mathrm{a}$ & $0.50 \mathrm{~b}$ & $8.73 \mathrm{c}$ & $4.43 \mathrm{~d}$ & $41.0 \mathrm{~b}$ & $0 \mathrm{~b}$ & $0 \mathrm{c}$ \\
\hline & $\mathrm{H}-\mathrm{WF}$ & $1.45 \mathrm{ab}$ & $4.46 \mathrm{~b}$ & $0.61 \mathrm{a}$ & $5.88 \mathrm{~d}$ & $4.43 \mathrm{~d}$ & $39.3 \mathrm{~b}$ & $0 \mathrm{~b}$ & $0 \mathrm{c}$ \\
\hline
\end{tabular}

$\overline{\mathrm{z}} \mathrm{B}=$ black polyethylene mulch; $\mathrm{H}=$ hairy vetch mulch; $\mathrm{NF}=$ no fungicide applications were made (control); $\mathrm{TC}=\mathrm{ToM}-\mathrm{CAST}$ disease forecasting model for fungicide application was used; $\mathrm{WF}=$ a typical commercial weekly fungicide application was used.

${ }^{\mathrm{y} E \text { Electrolyte leakage. }}$

${ }^{\mathrm{x}}$ Means within day and column with different letters are statistically different at $P \leq 0.05 ; \mathrm{n}=18$ (firmness); $\mathrm{n}=6$ (all other variables). The mean comparisons for all variables except fungal growth were performed using pairwise contrasts with Sidak-adjusted $P$ values so that the overall significance level was 0.05 . For fungal growth comparisons, only the B-NF treatment had values that were not all zero. A $t$ test was used to reveal that the B-NF mean was different from zero at the $P=0.0193$.

wNot measured. 
transplanting, the vines were elevated and supported with a stake and string system.

Plants were fertilized four times during the growing season using ammonium nitrate supplied through the irrigation system on each occasion. Those plots containing hairy vetch mulch were fertilized at a total rate of $100 \mathrm{~kg} \cdot \mathrm{ha}^{-1}$, whereas black polyethylene mulch plots received ammonium nitrate at a rate of $200 \mathrm{~kg} \cdot \mathrm{ha}^{-1}$.

Three fungicide treatments were examined in this study. One treatment was a weekly fungicide application program typically used by commercial growers (WF). This treatment began on 18 July and continued through 19 Sept. 1997. In 1999, the weekly program ran from 3 July through 3 Sept. Another treatment consisted of no fungicide application (NF). The third treatment was a spray schedule dictated by a disease forecasting model known as TOM-CAST (Brammall, 1993), which relies on measurements of leaf wetness duration and ambient temperature during the leaf wetness period to compute an infection index. Fungicide is applied when the number of accumulated infection units exceeds a predetermined acceptable level. Using the TOM-CAST model to create a rational spray schedule reduced fungicide input by $50 \%$ in 1997 and $33 \%$ in 1999 compared to the weekly spray treatment. The fungicidechlorothalonil(tetrachloroisophthalonitrile) was selected for use in this study and the active ingredient applied at a rate of $2.25 \mathrm{~kg} \cdot \mathrm{ha}^{-1}$.

SAMPLING AND ANALYSIS. To remove field heat and obtain fruit of uniform color, harvested fruit were stored at $20^{\circ} \mathrm{C}$ for $24 \mathrm{~h}$ and then selected visually for the study based on surface color when they had reached the light-red or red-ripe stage of ripeness. The NF treated plants showed a high incidence and severity of early blight [Alternaria solani (Ellis and Martin) Jones and Grout]. Also, fruit were sorted for absence of visual defects, as well as uniform appearance and size, ranging in weight from 220 to 240 g. Fruit were washed with water and then air dried. Six to seven slices ( $7 \mathrm{~mm}$ thick) were cut from the stem end with a meat slicer (model 827; Berkel, Inc., La Porte, Ind.). The fourth uniform tomato slices from the stem end of four tomatoes were placed in a 1-L commercial plastic fresh-cut produce container and held at either 5 or $20^{\circ} \mathrm{C}$.

For soluble solids content (SSC), pH, and titratable acidity (TA) analyses, tomato slice samples were first homogenized in a Waring blender. A refractometer, $\mathrm{pH}$ meter, and an autotitrator were then used to estimate SSC and TA, respectively. TA was measured by titrating the sample to $\mathrm{pH} 8.2 \mathrm{using} 0.1 \mathrm{~mol} \cdot \mathrm{L}^{-1}$ $\mathrm{NaOH}$. Acidity was expressed as an acid meq factor of 0.0655 . In particular, TA was measured in locular, pericarp, and whole tissues.

Firmness was measured in pericarp tissue by a puncture test using a texture analyzer (TA.XT2i, Texture Technologies, Scarsdale, N.Y.) using the following parameters: 4-mm-diameter stainless steel cylinder probe; a speed of $1 \mathrm{~mm} \cdot \mathrm{s}^{-1}$; and a $3.5 \mathrm{~mm}$ penetration distance. Firmness was expressed as maximum force and was measured at two locations on each section of pericarp at $0,4,8$, and $12 \mathrm{~d}$ of storage $\left(5^{\circ} \mathrm{C}\right)$ or at $0,6,12$, and $24 \mathrm{~h}$ of storage $\left(20^{\circ} \mathrm{C}\right)$.

For electrolyte leakage analysis, three sections ( $\approx 0.5 \mathrm{~g}$ each) were excised from each of four slices and combined. Then, a total of four sections were selected at random and placed in $30 \mathrm{~mL} 0.4$ $\mathrm{mol} \cdot \mathrm{L}^{-1}$ mannitol and incubated for $6 \mathrm{~h}$ at $30^{\circ} \mathrm{C}$. Twenty milliliters of suspension was taken and conductivity measured using a conductance meter (YSI model 32, Yellow Springs, Ohio). Total electrolytes were determined on the same sample after it was frozen at $-20^{\circ} \mathrm{C}$ for $24 \mathrm{~h}$ and then thawed. Electrolyte leakage was expressed as a percentage of total electrolytes. Electrolyte leakage was determined after $0,4,8$, and $12 \mathrm{~d}$ of storage at $5^{\circ} \mathrm{C}$ or after $0,6,12$, and $24 \mathrm{~h}$ of storage at $20^{\circ} \mathrm{C}$.

Enumeration of microorganisms was performed as described by Babic and Watada (1996). Potato dextrose agar (PDA; Difco, Detroit, Mich.) with the addition of chloramphenicol $\left(0.5 \mathrm{~g} \cdot \mathrm{L}^{-1}\right)$ was used for the yeasts and fungi. Tomato tissues $(20 \mathrm{~g})$ were macerated in $40 \mathrm{~mL}$ sterile pepton water ( $\mathrm{pH} 7.4)$ with a $400 \mathrm{Lab}$ Stomacher (Seward Medical, London). A sample of each homogenate or appropriate dilution was spread on agar plates using a spiral plate system (Autoplate Model 3000, Spiral Biotech, Bethesda, Md.); plates were incubated at $30^{\circ} \mathrm{C}$ for $48 \mathrm{~h}$.

Individual fruit slices were placed in $1 \mathrm{~L}$ jars at $5{ }^{\circ} \mathrm{C}$ and ethylene production was monitored using an automatic sampling, flow-through system as described previously (Watada and Massie, 1981). For analysis of the accumulated $\mathrm{CO}_{2}$ level in containers during storage, a 3-mL headspace sample was taken periodically and measured using a $\mathrm{CO}_{2}$ analyzer (АMETEK Pittsburgh, Pa.). Chilling injury was expressed as the percentage of slices showing water soaked areas, i.e., number of slices with water soaked areas per number of investigated slices multiplied by 100 .

STATISTICAL Analysis. The variables firmness and SSC were analyzed as four-factor mixed linear models using the MixED procedure of SAS (SAS Inst., Inc., Cary, N.C.) (Table 1). Mulch, fungicide treatment, and day were the fixed factors whereas year was a random factor. The five variables: electrolyte leakage, ethylene production, TA, $\mathrm{pH}$, and $\mathrm{CO}_{2}$ were analyzed as threefactor (mulch, fungicide treatment and day) linear models with Proc MiXed. Firmness, $\mathrm{CO}_{2}$, and ethylene data were natural log transformed to correct variance heterogeneity. The variance grouping technique was used with all seven variables. The variable yeast colony number was analyzed as a one-factor linear model where the factor had three levels (black polyethylene + no fungicide, black polyethylene + ToM-CAST, hairy vetch + no fungicide). Yeast colony number was natural log transformed to correct variance heterogeneity. The number of fungal colonies were recorded only on day 12 . A $95 \%$ confidence interval for the fungal colony mean was calculated and did not include zero (7.59 -31.07), showing that the average mold was not zero. Comparison of chilling injury percentages among treatments was found using StatXact (CYTEL Software Corp.) to calculate exact tests between proportions from binomial distributions (Table 2).

Table 2. Chilling injury (percentage of slices showing water-soaked areas) of fresh-cut slices from tomatoes grown using black polyethylene or hairy vetch mulches under various foliar disease management systems after $12 \mathrm{~d}$ storage at $5^{\circ} \mathrm{C}$ under modified atmosphere.

\begin{tabular}{lccc}
\hline \hline Mulch & NF $^{\mathrm{z}}$ & TOM-CAST $^{\mathrm{y}}$ & WF $^{\mathrm{x}}$ \\
\hline & Chilling injury $(\%$ water-soaked areas & \\
Black polyethylene & $47 \mathrm{a}^{\mathrm{v}}$ & $19 \mathrm{ab}$ & $28 \mathrm{ab}$ \\
Hairy vetch & $22 \mathrm{ab}$ & $6 \mathrm{~b}$ & $13 \mathrm{ab}$
\end{tabular}

${ }^{\mathrm{z} N F}=$ no fungicide applications were made (control).

yThe TOM-CAST disease forecasting model for fungicide application was used.

${ }^{\mathrm{x}} \mathrm{WF}$, a typical commercial weekly fungicide application was used.

${ }^{w}$ [Number of slices with water-soaked areas/number of slices $\left.(32)\right] \times$ 100.

${ }^{v}$ Means with different letters are statistically different at the $P<0.05$ significance level using Fisher's exact test for proportions from binomial distributions. Then pair-wise comparisons were made with Sidak-adjusted $P$ values so that the overall significance level was 0.05 . 


\section{Results}

Overall, the firmness of red-ripe tomato slices during storage was significantly higher $(P=0.004)$ for plants grown with hairy vetch mulch compared to black polyethylene. There were significant differences in firmness of slices from plants given different fungicide treatments (Table 1). After $12 \mathrm{~d}$ storage at $5^{\circ} \mathrm{C}$, only the firmness means for tomatoes grown with black polyethylene mulch under TOM-CAST or NF differed significantly from the means at initial storage. The black polyethylene mulch with NF slices decreased $41 \%$ from their initial firmness during storage.

The SSC in all slices remained relatively stable or increased up to $8 \mathrm{~d}$ storage and then declined (Table 1). With both NF and ToMCAST fungicide treatments, hairy vetch mulch had higher SSC than black polyethylene mulch after $12 \mathrm{~d}$ storage.

The TA of the black polyethylene mulch with NF was significantly higher than with TOM-CAST or WF up to $4 \mathrm{~d}$ storage (Table 1). For slices from tomatoes grown using hairy vetch mulch with TOM-CAST or WF, TA generally decreased during storage, but not with NF. The TA of the hairy vetch mulch with WF treatment was higher than that of any other mulch - fungicide treatment combination during storage.

The ratios of SSC to TA for the black polyethylene mulch with Tом-CAST or WF were consistently $>10$ during storage (Table 1). Hairy vetch with either TOM-CAST or WF exhibited a gradual increase in the ratio of SSC:TA until day 8 and then decreased gradually. However, slices from fruit grown using hairy vetch with NF showed a relatively rapid decrease in the SSC:TA ratio up to $8 \mathrm{~d}$ storage.

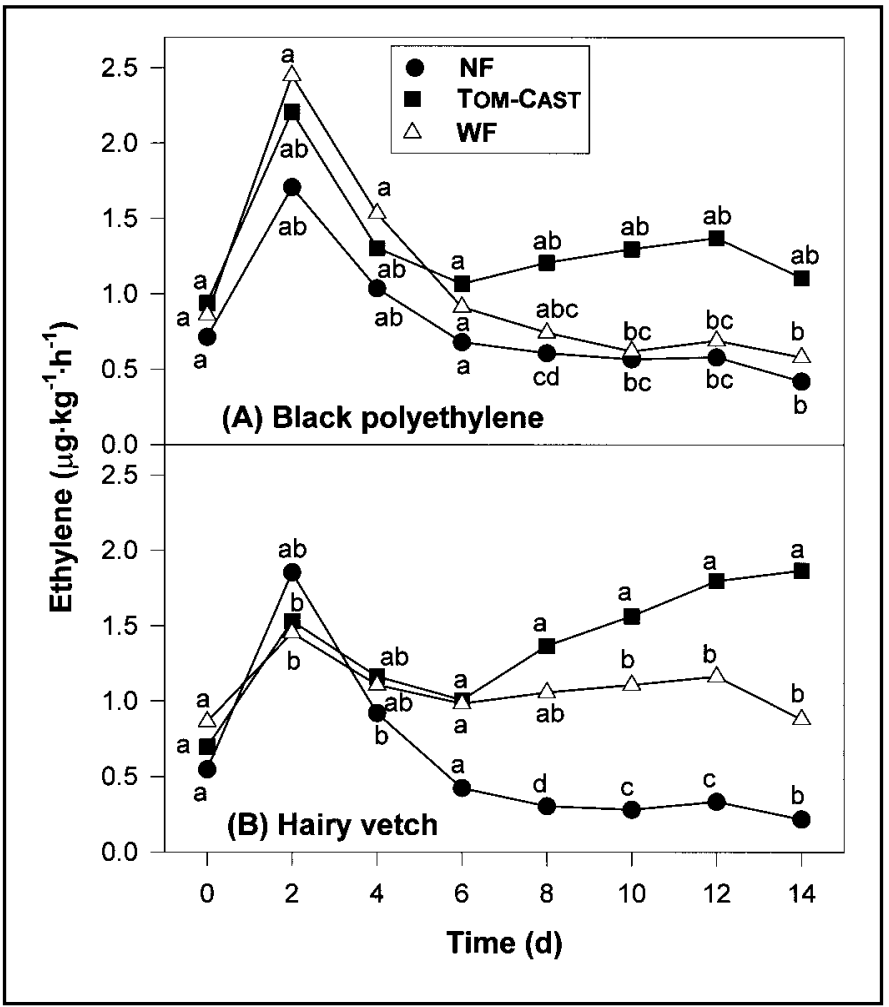

Fig. 1. Changes in $\mathrm{C}_{2} \mathrm{H}_{4}$ production of slices from 'Sunbeam' red tomatoes grown with (A) black polyethylene or (B) hairy vetch mulch with no fungicide application (NF), fungicide application based on the predictive disease forecasting model (TOM-CAST), and weekly fungicide applications (WF) during storage at $5{ }^{\circ} \mathrm{C}$. Initial, 0-time measurements were actually made $6 \mathrm{~h}$ after slicing. Across the mulches, means within days with different letters are significantly different at $P \leq 0.05 ; \mathrm{n}=3$.
Slices from tomatoes grown with hairy vetch mulch had lower mean $\mathrm{pH}$ at $0 \mathrm{~d}$ than those grown with black polyethylene mulch (Table 1). For the hairy vetch mulch, there were no significant differences in $\mathrm{pH}$ with the various fungicide treatments. While the $\mathrm{pH}$ of the black polyethylene or hairy vetch mulch with NF increased gradually, the $\mathrm{pH}$ in the treatments remained relatively stable throughout the storage period. After $12 \mathrm{~d}$ storage, the black polyethylene mulch with NF treatment showed the highest $\mathrm{pH}$ compared to the other treatments.

Comparison of electrolyte leakage for the slices revealed a similar trend during storage, except for the black polyethylene with NF treatment (Table 1). A small increase in electrolyte leakage was observed with all slices during storage, but at $12 \mathrm{~d}$ the black polyethylene with NF treatment showed the greatest electrolyte leakage, substantially higher than the other treatment combinations.

After $12 \mathrm{~d}$ storage, the population of fungal growth for the black polyethylene mulch with NF treatment was 21 colony forming units $(\mathrm{cfu}) / \mathrm{g}$, whereas the other treatments showed no fungal growth (Table 1). Yeasts were not found in either mulch with WF or hairy vetch mulch with ToM-CAST (Table 1). In contrast, the mean number of yeast colonies from the black polyethylene mulch with NF was higher than the other treatments. Also, in black polyethylene mulch with TOM-CAST and hairy vetch with NF treatments, yeasts were observed.

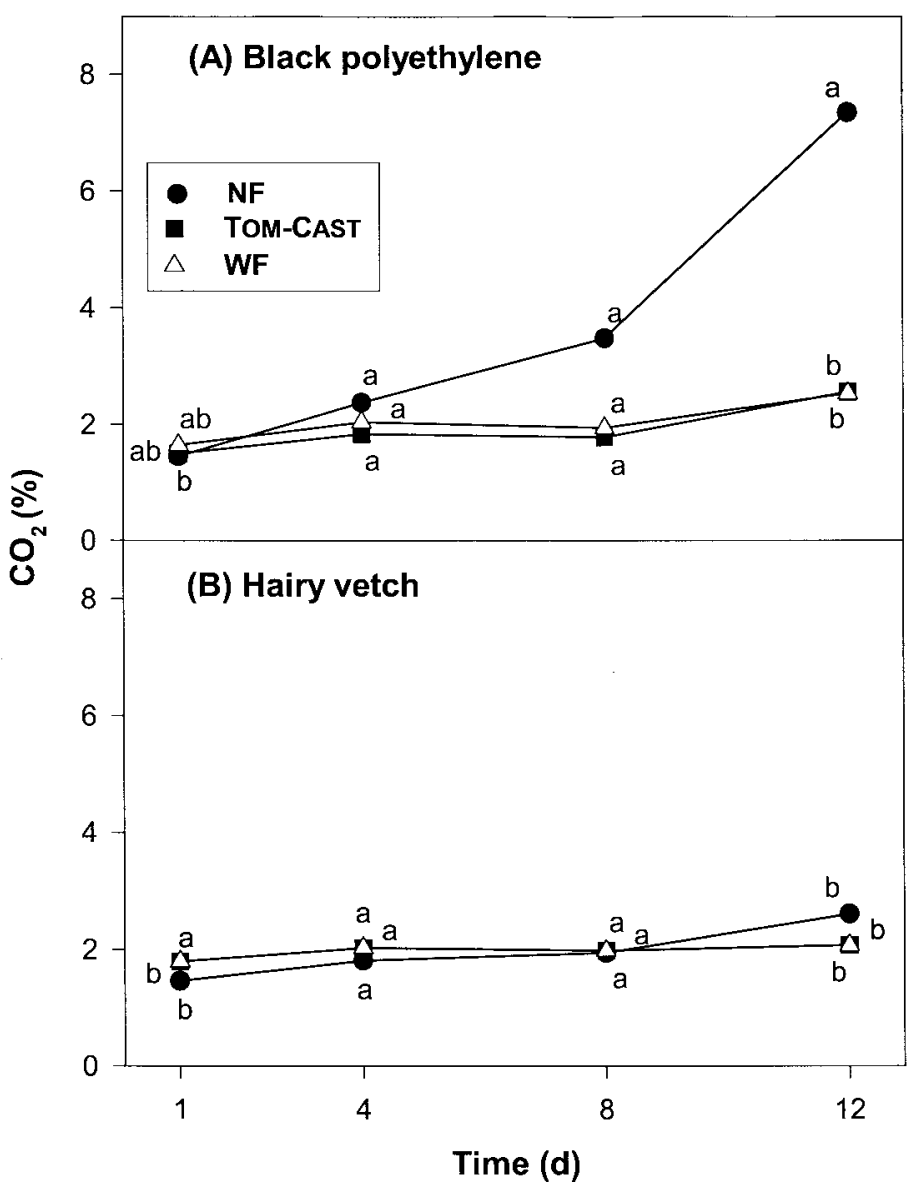

Fig. 2. Changes in $\mathrm{CO}_{2}$ concentration in containers with slices from 'Sunbeam' red tomatoes grown with (A) black polyethylene or (B) hairy vetch mulch with no fungicide application (NF), fungicide application based on the predictive disease forecasting model (TOM-CAST), and weekly fungicide applications (WF) during storage at $5^{\circ} \mathrm{C}$. Across the mulches, means within days with different letters are significantly different at $P \leq 0.05 ; \mathrm{n}=3$. 
Slices from red tomatoes grown using black polyethylene mulch under the three fungicide treatments had significant increases in ethylene production at $2 \mathrm{~d}$, then decreased (Fig. 1). From $6 \mathrm{~d}$ on, the ethylene production rate of the black polyethylene with Tом-CAST treatment remained above those of black polyethylene with NF or WF, although there were no significant differences in ethylene production among treatments. Ethylene production of slices from plants grown using the hairy vetch treatment increased at $2 \mathrm{~d}$, then decreased similar to black polyethylene during storage. After storage for $8 \mathrm{~d}$, however, differences in ethylene production rate among the treatment combinations was significant. After $12 \mathrm{~d}$, the rate of ethylene production for hairy vetch with TOM-CAST was $\approx 1.5$ - and 5-fold higher than that for hairy vetch with WF or NF, respectively.

The $\mathrm{CO}_{2}$ concentration in containers with slices from the black polyethylene with NF treatment increased during storage, while there was little or no accumulation of $\mathrm{CO}_{2}$ in containers with slices from the other treatments (Fig. 2). The $\mathrm{CO}_{2}$ concentration during storage for the black polyethylene with NF treatment was significantly different from the other treatment combinations which were not significantly different from each other.

Chilling injury, as measured by the percentage of watersoaked areas in the slices, was highest for the black polyethylene mulch under NF treatment. The percentage of water-soaked areas from this treatment was $>7$-fold greater than that of the hairy vetch under TOM-CAST treatment, which had the lowest chilling injury (Table 2). These two treatments were significantly different from each other while the other treatments were not significantly different. Within the same fungicide treatment, hairy vetch consistently had less chilling injury than the black polyethylene

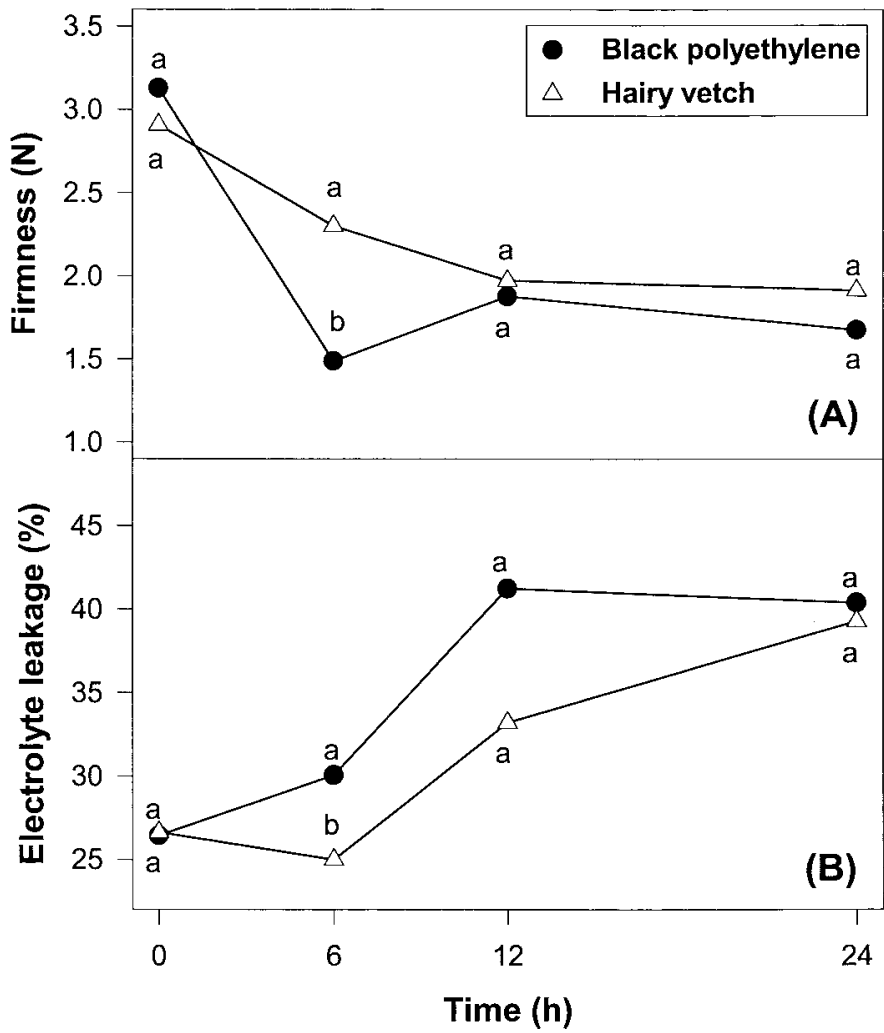

Fig. 3. (A) Changes in firmness and (B) electrolyte leakage for slices from 'Sunbeam' light-red tomatoes grown with black polyethylene or hairy vetch mulch with weekly fungicide applications (WF) during storage at $20^{\circ} \mathrm{C}$. Means within days with different letters are significantly different at $P \leq 0.05 ; \mathrm{n}=9$ (firmness); $\mathrm{n}=3$ (electrolyte leakage). mulch, although not statistically significant.

Firmness and electrolyte leakage for the black polyethylene and hairy vetch mulches with WF during storage at $20^{\circ} \mathrm{C}$ is illustrated in Fig. 3. Firmness for the black polyethylene mulch decreased dramatically after $6 \mathrm{~h}$ (Fig. 3A). In contrast, the hairy vetch treatment declined gradually during the $24 \mathrm{~h}$ period. There was a significant difference between the treatments in firmness at $6 \mathrm{~h}$. Slices from tomatoes grown using both the black polyethylene and hairy vetch mulches showed a rapid increase in electrolyte leakage after $6 \mathrm{~h}$ (Fig. 3B). The hairy vetch mulch tended to have less electrolyte leakage than the black polyethylene. However, only at $6 \mathrm{~h}$ was there a significant difference between the treatments.

\section{Discussion}

At $0 \mathrm{~d}$ storage, slices from tomatoes grown using both the black polyethylene and hairy vetch mulches under NF had lower SSC than those under the other fungicide application regimens, i.e., WF or Tom-CAST (Table 1). The amount of reducing sugars in tomatoes generally correlates with SSC (Jones and Scott, 1984). McCollum and Skok (1960) observed that when ${ }^{14} \mathrm{C}$ glucose was applied to tomato leaves, it was translocated most rapidly into fruit. Thus, our results may reflect an effect of the foliar fungicide treatment on the ability of leaves to export sufficient amounts of photosynthate to the fruit.

At $0 \mathrm{~d}$, slices from tomatoes grown using hairy vetch mulch with NF or Tom-CAST had higher SSC than those using black polyethylene mulch (Table 1). In both 1997 and 1999, we observed that plants grown with hairy vetch mulch had less foliar disease than those grown with black polyethylene mulch. Therefore, this higher SSC in the hairy vetch mulch grown tomatoes may have been due to the increase in carbohydrates in the leaf by higher photosynthesis compared to the black polyethylene mulch grown plants. However, Abdul-Baki et al. (1996) have reported that SSC was similar for all mulch types studied, including black polyethylene and hairy vetch.

Initial $\mathrm{pH}$ values in this experiment were sufficiently low to be considered safe (Table 1), as they were below the food safety threshold of 4.7 (Field et al., 1977). In particular, the $\mathrm{pH}$ values from the hairy vetch with TOM-CAST or WF treatments were very low with a mean $\mathrm{pH}$ of 4.37 and 4.38 , respectively. After $12 \mathrm{~d}$ storage, all treatments, with the exception of black polyethylene mulch with $\mathrm{NF}$, had $\mathrm{pH}<4.6$. We detected a substantial loss in TA in slices from black polyethylene mulch under NF and observed concomitantly visible infection by fungi. Beaulieu and Saltveit (1995) observed that fungal growth accelerated the loss of TA. In the present study, TA of pericarp was invariably lower than that of locular tissue with visible fungal infection appearing earlier on pericarp than on locular tissue, generally when the TA was below $0.3 \%$ (data not presented). Therefore, we suggest that a TA higher than 0.3 ( 0.0655 as acid meq factor) may inhibit fungal infection.

While some investigators have reported that the SSC:TA ratio is important in defining flavor differences among various tomato cultivars (Stevens, 1972), others suggest that the flavor of tomatoes can be enhanced by increasing total sugar and acid content (Jones and Scott, 1984). Maintenance of high sugar and TA is essential for high quality fresh market-ripe fruit (Kader et al., 1977). Kader et al. (1978) suggested that high-quality tomatoes are characterized by SSC of more than 3, TA more than $0.32 \%$, and having a SSC:TA ratio $>10$ ( $\mathrm{pH} 8.1$, expressed as citric acid). We observed SSC:TA ratios during storage consistently $>10$ for 
the black polyethylene mulch with some of the fungicide application treatments, whereas slices from tomatoes grown using hairy vetch with WF had a SSC:TA ratio <10 (Table 1).

All slices showed an ethylene production peak at $2 \mathrm{~d}$ storage (Fig. 1), most likely the result of a cutting-induced wound response (Yang and Hoffman, 1984). However, slices from tomatoes grown using hairy vetch under TOM-CAST showed a second rise in ethylene production after $6 \mathrm{~d}$ storage; the other treatment combinations did not.

Fruit infected by fungi frequently show a rise in $\mathrm{CO}_{2}$ production during storage (Hong and Gross, 1998; Zauberman and Barkai-Golan, 1975). Barkai-Golan and Kopeliovitch (1983) reported that Rhizopus stolonifer (Ehrneb. ex Fr.) infection stimulated $\mathrm{CO}_{2}$ production and induced development of climactericlike respiratory patterns in two nonripening tomato mutants, rin and nor. Although, red tomatoes generally show a postclimacteric decline in respiration, we observed after $8 \mathrm{~d}$ storage dramatic increases in $\mathrm{CO}_{2}$ concentration in the container with slices from the black polyethylene mulch with NF (Fig. 2). Also, fungi were detected only in slices from red tomatoes grown using black polyethylene mulch with NF treatment (Table 1). Therefore, it seems likely that the increase in $\mathrm{CO}_{2}$ concentration was due to fungal infection.

In slices from tomatoes grown using black polyethylene mulch, electrolyte leakage after $8 \mathrm{~d}$ storage was $20 \%$ less with NF than with the Tom-CAST fungicide application (Table 1). As described previously, mealiness appeared in slices of tomatoes grown with NF but not with TOM-CAST, indicating that the NF fruit may be more chilling-sensitive than the Tом-CAST. These results may be attributed to increases in pectin demethylation by pectin methylesterase during chilling (Jackman et al., 1992), which increased the number and availability of carboxyl groups for binding with calcium, other ions and water, thereby reducing the amount of measured electrolyte leakage and inducing mealiness (Harker and Sutherland, 1993). It was observed that water soaked areas were induced more easily in slices from the black polyethylene treatment than the hairy vetch (Table 2). Regardless of mulch type, the Tом-CAST fungicide application resulted in lower chilling injury incidence than any other treatment.

Electrolyte leakage is generally considered to be an indirect measure of plant cell membrane damage (King and Ludford, 1983) and it has been used to determine the extent of chilling injury. Murata (1990) observed dramatic increases in electrolyte leakage in cucumber (Cucumis sativus L.), melon (Cucumis melo L.) and winter squash (Cucurbita maxima Duchesne ex Lam.) stored at $0{ }^{\circ} \mathrm{C}$. However, Kuo and Parkin (1989) reported that cucumber showed no changes in ion leakage during storage at $2{ }^{\circ} \mathrm{C}$. The same observation in tomatoes, chilled for $20 \mathrm{~d}$ at $5{ }^{\circ} \mathrm{C}$, was reported by Sharom et al. (1994). We observed that slices from tomatoes grown using black polyethylene with NF, which had the highest electrolyte leakage (Table 1), showed the highest chilling injury symptoms (Table 2). A significant difference during storage at $20^{\circ} \mathrm{C}$ was noted in electrolyte leakage between black polyethylene and hairy vetch with WF (Figure 3B). A rapid increase in electrolyte leakage for black polyethylene with WF, compared to hairy vetch with WF, may have been due to a change in membrane fluidity by cutting-induced oxidative stress (Hong and Gross, 1998). Therefore, this difference suggests that slices from tomatoes grown using black polyethylene mulch may be more susceptible to oxidative stress than those from tomatoes grown using hairy vetch as a mulch.

We observed differences in the quality of tomato slices during storage at $5^{\circ} \mathrm{C}$ between black polyethylene and hairy vetch mulch and also among the foliar disease management systems (NF, TOM-CAST and WF). Our results from experiments in both 1997 and 1999 suggest that fruit grown using hairy vetch as a mulch may be more suitable for fresh-cut slices than those grown using a black polyethylene mulch system because all the measured quality parameters, except for SSC:TA ratios, were better. Also, use of predictive models appropriate for sustainable systems, such as TOM-CAST, may be a good alternative for minimizing fungicide application while producing high quality tomatoes for fresh-cut preparation. However, the mechanism(s) by which hairy vetch as a cover crop and TOM-CAST as a foliar disease management system affect tomatoes quality remain to be elucidated.

\section{Literature Cited}

Abdul-Baki, A.A., C. Spence, and R. Hoover. 1992. Black polyethylene mulch doubled the yield of fresh-market field tomatoes. HortScience 27:787-789.

Abdul-Baki, A.A., J.R. Stommel, A.E. Watada, J.R. Teasdale, and R.D. Morse. 1996. Hairy vetch mulch favorably impacts yield of processing tomatoes. HortScience 31:338-340.

Abdul-Baki, A.A. and J.R. Teasdale. 1993. A no-tillage tomato production system using hairy vetch and subterranean clover mulches. HortScience 28:106-108.

Babic, I. and A.E. Watada. 1996. Microbial populations of fresh-cut spinach leaves affected by controlled atmospheres. Postharvest Biol. Technol. 9:187-193.

Barkai-Golan, R. and E. Kopeliovitch. 1983. Induced ethylene evolution and climacteric-like respiration in Rhizopus-infected rin and nor tomato mutants. Physiol. Plant Pathol. 22:357-362.

Beaulieu, J.C. and M. Saltveit. 1995. Ripe tomatoes stored under controlled atmosphere. Intl. J. Food Sci. Technol. 30:379-389.

Bhella, H.S. 1988. Tomato response to trickle irrigation and black polyethylene mulch. J. Amer. Soc. Hort. Sci. 113:543-546.

Brammall, R.A. 1993. Effect of foliar fungicide treatment on early blight and yield of fresh market tomato in Ontario. Plant Dis. 77:484-488.

Field, M.L., A.F. Zamora, and M. Bradsher. 1977. Microbiological analysis of home-canned tomatoes and green beans. J. Food Sci. 42:931-934.

Harker, J.R. and P.W. Sutherland. 1993. Physiological changes associated with fruit ripening and the development of mealy texture during storage of nectarines. Postharvest Biol. Technol. 2:269-277.

Ham, J.M., G.J. Kluitenberg, and W.J. Lamont. 1993. Optical properties of plastic mulches affect the field temperature regime. J. Amer. Soc. Hort. Sci. 118:188-193.

Haynes, K.F., M.P. Parella, J.T. Trumble, and T.A. Miller. 1986. Monitoring insecticide resistance with yellow sticky cards. Calif. Agr. 40:11-12.

Hochmuth, G.J., D.N. Maynard, and AA. Czizinszky. 1986. Fertilizing polyethylene-mulched vegetables with a liquid fertilizer injection wheel. Proc. Natl. Agr. Plastics Congr. 19:249-255.

Hong, J.H. and K.C. Gross. 1998. Surface sterilization of whole tomato fruit with sodium hypochlorite influences subsequent postharvest behavior of fresh-cut slices. Postharvest Biol. Technol. 13:51-58.

Hoyt, G.D. and W.L. Hargrove. 1986. Legume cover crops for improving crop and soil management in the southern United States. HortScience 21:397-402.

Jackman, R.L., H.J. Gibson, and D.W. Stanley. 1992. Effects of chilling on tomato fruit texture. Physiol. Plant 86:600-608.

Jones, R.A. and S.J. Scott. 1984. Genetic potential to improve tomato flavor in commercial $F_{1}$ hybrids. J. Amer. Soc. Hort. Sci. 109:318-321.

Kader, A.A., L.L. Morris, M.A. Stevens, and M. Albright-Holton. 1978. Composition and flavor quality of fresh market tomatoes as influenced by some postharvest handling procedures. J. Amer. Soc. Hort. Sci. 103:6-13. 
Kader, A.A., M.A. Stevens, M. Albright-Holton, L.L. Morris, and M. Algazi. 1977. Effect of fruit ripeness when picked on flavor and composition in fresh market tomatoes. J. Amer. Soc. Hort. Sci. 102:724-731.

King, M.M. and P.M. Ludford. 1983. Chilling injury and electrolyte leakage in fruit of different tomato cultivars. J. Amer. Soc. Hort. Sci. 108:74-77.

Kuo, S. and K.L. Parkin. 1989. Chilling injury in cucumber (Cucumis sativa $\mathrm{L}$.) associated with lipid peroxidation as measured by ethane evolution. J. Food Sci. 54:1488-1491.

McCollum, J.P. and J. Skok. 1960. Radiocarbon studies on the translocation of organic constituents into ripening tomato fruits. Proc. Amer. Soc. Hort. Sci. 75:611-616.

McVay, K.A., D.E. Radcliffe, and W.L. Hargrove. 1989. Winter legume effects on soil properties and nitrogen fertilizer requirements. J. Amer. Soc. Soil Sci. 53:1856-1862.

Murata, T. 1990. Relation of chilling stress to membrane permeability, p. 201-209. In: C.Y. Wang (ed.). Chilling injury of horticultural crops. CRC Press, Boca Raton, Fla.

Perry, K. and D.C. Sanders. 1986. Tomato yield as influenced by plant protection system. HortScience 21:238-239.

Sharom, M., C. Willemot, and J.E. Thompson. 1994. Chilling injury induces lipid phase changes in membranes of tomato fruit. Plant Physiol. 105:305-308.

Shelton, C.H. and J.F. Bradley. 1987. Controlling erosion and sustaining production with no-till systems. Tenn. Farm Home Sci. 141:18-23.

Sloderbeck, P.E. and C.R. Edwards. 1979. Effects of soybean cropping practices on Mexican bean beetle and redlegged grasshopper populations. J. Econ. Entomol. 72:850-853.

Stevens, M.A. 1972. Relationships between components contributing to quality variation among tomato lines. J. Amer. Soc. Hort. Sci. 97:7073.

Stivers, L.J. and C. Shennan. 1991. Meeting the nitrogen needs of processing tomatoes through winter cover cropping. J. Prod. Agr. $4: 330-335$.

Teasdale, J.R. and D. Colacicco. 1985. Weed control systems for fresh market tomato production on small farms J. Amer. Soc. Hort. Sci. 110:533-537.

Teasdale, J.R. and C.L. Mohler. 1993. Light transmittance, soil temperature and soil moisture under hairy vetch and rye. Agron. J. 85:673-680.

Trumble, J.T., W.G. Carson, and K.K. White. 1994. Economic analysis of a Bacillus thuringiensis based integrated pest management program in fresh-market tomatoes. J. Econ. Entomol. 87:1463-1469.

Watada, A.E. and D.R. Massie. 1981. A compact automatic system for measuring $\mathrm{CO}_{2}$ and $\mathrm{C}_{2} \mathrm{H}_{4}$ evolution by harvested horticultural crops. HortScience 16:39-41.

West, J. and L.C. Pierce. 1988. Yields of tomato phenotypes modified by planting density, mulch, and row covers. HortScience 23:321-324.

Yang, S.F. and N.E. Hoffman. 1984. Ethylene biosynthesis and its regulation in higher plants. Annu. Rev. Plant Physiol. 35:155-189.

Zauberman, G. and R. Barkai-Golan. 1975. Changes in respiration and ethylene evolution induced by Diplodia natalensis in orange fruit. Phytopathology 65:216-217. 